\title{
幼児における事物名解釈方略の発達的検討
}

一一相互排他性と文脈の利用をめぐって——

\author{
針 生 悦 子*
}

\section{A DEVELOPMENTAL STUDY OF CHILDREN'S USE OF 'MUTUAL EXCLUSIVITY' AND CONTEXT TO INTERPRET NOVEL WORDS}

\author{
Etsuko HARYU
}

There are an indefinite number of logically possible hypotheses about the meaning of a word. Since children broaden their vocabulary so rapidly, they must be constrained to give priority to some hypotheses. 'Mutual exclusivity' (children assume that an object has only one label) was proposed as one of such constraints by Markman (1987). If children have such a constraint, a novel label for a familiar object should be rejected, even when the context shows it clear that the label refers to the familiar object. Study 1 and 2 tested this hypothesis with 3 -year-olds and confirmed it. Study 3 and 4 showed that children, as they grew up, came to take more of the context where the label was used than mutual exclusivity, and as a result of such change in strategy to interpret novel words, 5-year-olds came to accept the second label for a familiar object when it was presented in an appropriate context.

Key words : constraint, mutual exclusivity, context, change in strategy to interpret novel words.

\section{問題}

鈴木 (1973)によれば, 語の意味 (語意) は，その語に よって喚起される経験の総体である。したがって, 事 物を指さしてその名前を言うという指示定義(ostensive definition)は，事物を見るという経験の上にラベルを与 えるものであり，語を定義する最も簡単な方法と言え る。しかしそれは曖昧でもある。例えば，うさぎを指 さし「gavagai」と言われたとしても，それだけでは “gavagai”が“うさぎ”という事物カテゴリーを指す のか, “白い”や“毛がふさふさしている”といった属 性を指すのか, “耳”や“しっぼ”などの部分を指すの かは定かでないからである。事物を見るという経験は 話し手と聞き手の間で共有されていても，話し手が事

* 東京大学教育学研究科 (Department of Educational Psychology, Faculty of Education, University of Tokyo)
物のどの側面に注目してその語を発したのかというこ とまで指示定義ではわからない。語意を明らかにする ためには，指示された対象に基づき，語意についでう さぎ”“白い”などの仮説を立て, “gavagai”という語 を実際に“茶色いうさぎ“や“白い布”に試してみて, それに対する相手の反応から仮説を検証していかなけ ればならないのである (Quine, 1960)。

子どもの語の学習も, 多くはこのように曖昧な指示 定義を通じてなされる(Carey, 1982)。語意として考えう る仮説は無数にあるが, その中から子どもはいかにし て正しい語意に達することができるのだろうか。

他者との相互作用を重視する立場（相互作用論）から は，これが，複雑な仮説検証のプロセスであると見な されてきた(例えば, Bruner, Olver \& Greenfield, 1966 ; Clark \& Clark, 1977 ; Nelson, 1988)。すなわち, 子どもは他者 とやりとりする中で，その語がどんな文脈で使われた か, 自分の使った語に相手がどのように反応したかと 
いったことに照らして, 語意を帰納的に推論していく と考えられてきたのである。

しかし 1 歳半以降, 子どもの語彙獲得は爆発的な勢 いで進む。そもそも就学前児にとっては，一度持った 仮説を, 後続の否定的な情報に照らして修正していく ことさえ難しい(Markman, 1987)。語意について立てう る仮説の数は無限であるが, 子どもの語彙獲得の過程 が，その仮説をすべて提出し，1つ1つ検証していく ような複雑なプロセスであるとは考えにくい。子ども の語意仮説がどのような種類のものであるかについて は何か制約 (constraint) が働いているはずである (Carey, 1982)。そして，子どもが爆発的な勢いで語彙を獲得し ていくことを説明するためには，このような制約，す なわち, 子どもが語意仮説を立てるとき何がその源泉 になっているのかが，明らかにされなければならない だろう。

この制約理論の立場は, 何を語意仮説の源泉と見な すかによって,さらに二分される。その第 1 のものは, 課題解決一般を支配している非言語的な反応バイアス が，言語獲得においても制約として働いているとする 立場である。例えば Clark(1973)は, “Put the X in [on, under] the Y.”という教示に対して年齢の低い子ども は, 前置詞が何であれ'Yが入れ物なら Xをその中に入 れる’, 'Yが水平な支持面を持つなら $\mathrm{X}$ をその上にのせ る’といった 2 つ規則に従い事物操作することを見 いだした。またこの課題での正答率は “in”“on” “under”の順に高く, これは, 子どもの反応バイアスに より近い意味を持つ前置詞が, より早く獲得されるこ とを示すもののようであった。そこで, Clark (1973, 1977)はこの結果に基づいて, 子どもは与えられた状況 をあるやり方で表象し解釈するようなバイアスを持っ ており，それが語意仮説の源泉になっていると主張し た。

しかし，非言語的な反応バイアスが語意仮説の源泉 になっているとする見方は, 以下の 2 つ理由から受 け入れ難いものである。第 1 に, 子どもが課題に特定 のやり方で反応するようなバイアスを持つということ は, その課題における子どものパフォーマンスを説明 しはする。しかしだからと言って，子どもは，その場 で自分のとった行動を, 与えられたことばの意味だと 考えるようになるとは限らない。第 2 に, 事物の分類 や語連想を取り上げた多くの研究（例えばGelman＆ Baillargeon, 1983 ; Smiley \& Brown, 1979) が，就学前児は， 例えば “犬と猫” のような事物のカテゴリー関係（taxonomic relation) より, “犬と骨”のような主題関係 (thematic relation)を選好することを見出している。し たがって, 非言語的な反応バイアスが語意仮説の源泉 になっているのであれば，就学前児が獲得する語は， 事物のカテゴリーを指すものというより, “犬と骨”の ように主題的に結びついた事物を指すものになるはず である。しかしこれは, 就学前児の獲得する語の多く がむしろ，事物のカテゴリ一名であるという事実に反 している。

この第 2 の批判点はさらに, 子どもの言語獲得が, それ固有の秩序のもとに進められていくものであるこ とを示唆している。すなわち子どもは, 例えば事物を 分類する基準としてはその主題関係を選好するが, 語 意を明らかにしようとするときには，そのままこのよ うなバイアスを転用するのではなく, 言語という領域 に限って適用されるような固有の規則に従っているの だと考えられる。ここから, 制約を言語に固有のもの と見なす制約理論の第 2 の立場が導き出される。Markman (1987，1989）の事物カテゴリ一制約（taxonomic constraint) と相互排他性制約 (mutual exclusivity constraint）も，このような制約として提出された。

このうちの事物カテゴリー制約とは, “語は類似した 事物のカテゴリー名である”との仮定を指し, 他方の

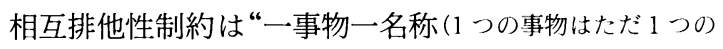
名前を持つ”の原則である。そして子どもがこれらの制 約を持つとすることによって, “子どもは事物を分類す る基準としては“犬と骨”のような主題関係を選好す るにもかかわらず, 語は類似した事物のカテゴリー名 として学習する (Markman \& Hutchinson, 1984)', ‘子ど もが初期に獲得する語の多くは相互に排他的な事物の カテゴリー名である (Macnamara, 1982 ; Mervis, 1980)', “りんごは“りんご”であると同時に“果物”でもある というように 1 つの事物が類包攝関係にある複数の名 称によって指示されうることを就学前児はなかなか理 解できない (Inhelder \& Piaget, 1964 ; Macnamara, 1982)’ など, 言語獲得の過程で見られる諸現象も, 説明され る (Markman, 1987 ; Markman, \& Wachtel, 1988)。

しかし，相互排他性制約の存在を示すべく, Markman ら (1988) の行った実験については, 次のような 2 つの問題点を指摘することができる。

彼らは，既に名前のわかっている事物（既知物）と名 前のわからない事物 (未知物) のうちから 1 つを選ぶ課 題において 3 歳児が, 「X (=新奇なラベル)をとって」と 言われると，「1つとつて」と言われたときより末知物 を多く選ぶようになることを示した。“X”に対して既 知物を選ぶことは，既に名前のわかっている事物にも 
う1つ新しいラベルを認めることになり, 相互排他性 制約に反する。したがって，この結果は確かに，どち らの事物を選ぶべきかについて新奇なラベル以外に手 掛かりがないような事態においては，3歳児が相互排 他性を方略的に用いうることを示唆している。しかし， そもそも制約理論の立場は, 子どもの言語獲得が，そ の語がどんな文脈で使われたか, 自分の使った語に相 手はどう反応したかなどから, 語意を帰納的に推論す る複雑な過程であることを, 否定するものである。そ してむしろ, 学習場面に存在するノイズを排し, 効率 的な語彙獲得を可能にしているものとして, 制約を提 出するのである。したがって，相互排他性がこのよう な制約であると言うためには, 相互排他性から導かれ る語の解釈が文脈から導かれる解釈と食い違うときに も, 前者が優先されるということが示されなければな らない。Markman ら (1988) は, この点で不十分なも のと言わざるをえない。これが第 10 点である。

第 2 に, 相互排他性制約は, 非言語的な反応バイア スを語意仮説の源泉と見なす立場に対して，制約を言 語に固有なものとする立場から提出されてきた。した がって，そのような制約の存否を論ずるなら，子ども のラベルの解釈こそが問題にされなければならない。 しかし, Markman ら (1988) が検討しているのは, 子 どもの事物選択にすぎないのである。

本研究は, 制約を言語に固有なものと見なす立場か ら，上で指摘したような Markman ら (1988) の問題点 を克服し，より厳密な事態において相互排他性制約の 存在を確かめることを第 1 の目的とする。具体的には, ラベルの指すものが既知物であることを示唆するょう な文脈の中で新奇なラベルが提示された場合，年少児 はそれに対してどのような事物選択を行い(実験 1), ラ ベルをどう解釈するのか (実験 2)について検討する。

そして,もしここで相互排他性制約の存在が確認さ れたなら, “同じ 1 つ事物が類包搨関係にある複数の名 称によって指示されることを, 就学前児はなかなか理 解できない (Inhelder \& Piaget, 1964 ; Macnamara, 1982)， ことも，このような制約の存在によって説明される (Markman, 1987, 1989 ; Markman \& Wachtel, 1988)。しか し，子どもはいずれ，上位語を獲得し，類包攝関係を も理解できるょうになっていく。とすれば，その過程 でこのような制約は乗り越えられなければならない。 それはいつ頃どのような形で達せられるのだろうか。 上と同様の事態における事物選択（実験 3) やラベルの 解釈(実験 4) に, どのような年齢変化が見られるか検討 し,この点を明らかにすることが, 本研究の第 2 の目
的である。

\section{実 験 1}

制約理論の立場は, 子どもによる言語獲得が, 文脈 から語意を推論したり, 他者とやりとりする中で仮説 を検証したりする複雑な過程であることをむしろ否定 する。そして, 語について他に可能な解釈を排し, 子 どもが効率よく語意に達することを可能にしているも のとして, 制約を提出する。したがって, ある方略が 制約になっていると言うためには, その方略によって 導かれる語の解釈が, 他に可能な解釈より優先される ことが示されなければならない。例えば, 新奇なラべ ルが，そのラベルの指すものが既知物であることを示 唆するような文脈の中で提示されるとき, 相互排他性 から導かれるラベルの解釈 (未知物を指す) と文脈から導 かれる解釈 (既知物を指す) は葛藤を起こす。このような 場合にも, 子どもは相互排他性に固執し, ラベルに対 応したものとして未知物を選ぶのだろうか。Markman ら (1988) はこのような形で制約の存否を検討して おらず, そこが彼らの研究の問題点の 1 つとして指摘 される。そこでこの実験 1 は, 既知物と末知物のうち から一方を選ぶ事態において, 新奇なラベルや既知物 に注意を向けさせるような文脈の提示が，年少児の事 物選択にどのように影響するか検討する。

\section{方 法}

被験者 保育園の年少児 64 名を 16 名ずつランダム に，ラベルなし・文脈なし $(\mathrm{L}[-] \mathrm{C}[-])$ 群 (平均 3 : 10 , レンジ $3: 4 \sim 4: 4)$, ラベルなし・文脈あり（L[-]C $[+]$ ) 群 (平均 $3: 10$, レンジ $3: 4 \sim 4: 5)$, ラベルあり・文 脈なし $(\mathrm{L}[+] \mathrm{C}[-])$ 群 (平均 $3: 10$, レンジ $3: 4 \sim 4: 4)$, ラベルあり, 文脈あり $(\mathrm{L}[+] \mathrm{C}[+])$ 群 (平均 $3: 11$, レンジ $3: 5 \sim 4: 3)$ にわりあてた。男女比は各条件とも 1：1であった。

材料 TABLE1に示す。事物については, 上の被験 児と別の年少児 12 名 (平均 $3: 9,3: 7 \sim 3: 11$ ) を対象に, その名称や用途，使用場面 (どんなときに使うものか)を尋 ね, 全員が既知物には命名でき, 未知物については名 前・用途・使用場面を知らないことが確かめられた。 ラベルは，梅本・森川・伊吹（1955）の無連想価が50以 上の無意味音節の中から選んだ。

手続 実験は保育園内の一室で個別に行った。被験 児にはメリーちゃんという人形が紹介される。課題は, 2 つの事物 (TABLE 1 に示したような既知物と末知物の七ッ ト)のうちから 1 つを選び, 人形に渡してあげること(強 制選択)である。このとき例えば, $\mathrm{L}[-] \mathrm{C}[-]$ 群には「メ 
Table 1 Stimulus Materials, Contexts and Novel Labels for Experiment 1 4.

\begin{tabular}{lccc}
\hline Familiar & Unfamiliar & Context & Label \\
\hline (1) クんご & リップミラー & おなかがすいている & おク \\
(2) 不けん & カンバスクリップ & 泥んこになってしまった & ミュ \\
(3) クレヨン & バッグハンガー & お絵書きをする & ソイ \\
(4) ハブラシ & パイ車 & 歯磨きをする & ルチ \\
(5) 靴 & ところてん押し出し器 & お外に行く & オヌ \\
\hline
\end{tabular}

リーちゃんに 1 つ渡してあげて」，L[-]C[+]群には 「メリーちゃんはお腹がすいています。1つ渡してあ げて」, L[+]C[-] 群には「メリーちゃんにへク（無 意味音節)を渡してあげて $J, \mathrm{~L}[+] \mathrm{C}[+]$ 群には「メリー ちゃんはお腹がすいています。へクを渡してあげて」 との教示が与えられ，その後で事物セットが提示され た。各被験児はこのような事物選択を，TABLE 1 に示 した 5 つの事物セットについて(1)〜(5)の順序で行った。

得点化 各セットで既知物を選択した場合に 1 点と して被験児ごとに 5 セットの合計を求め, 既知物選択 得点 ( $\mathrm{F}$ 得点) とした。

デザイン ラベルの有無 $(2) \times$ 文脈の有無 $(2)$

\section{結果と考察}

$\mathrm{F}$ 得点の平均 $(\mathrm{SD})$ は, $\mathrm{L}[-] \mathrm{C}[-]$ 群 2.6(.8), $\mathrm{L}[-]$ $\mathrm{C}[+]$ 群 4.7 (.7), $\mathrm{L}[+] \mathrm{C}[-]$ 群 1.1(1.0), $\mathrm{L}[+] \mathrm{C}[+]$ 群 3.4 (1.3) であった。分散分析の結果, 交互作用は有 意でなく $(F(1,60)=.06)$ ，ラベルの主効果 $(F(1,60)=30.83)$ と文脈の主効果 $(\mathrm{F}(1,60)=78.03)$ が $0.1 \%$ 水準で有意で あった。これは，新奇なラベルの提示によって既知物 が選択されにくくなり，文脈の提示によって既知物が より多く選択されるようになることを示している。ま た Tukey 法による対間比較から， F 得点は $\mathrm{L}[-] \mathrm{C}$ $[+]$ 群 $>\mathrm{L}[+] \mathrm{C}[+]$ 群 $>\mathrm{L}[-] \mathrm{C}[-]$ 群 $>\mathrm{L}[+] \mathrm{C}$ $[-]$ 群であることが示された $(\mathrm{p}<.05)$ 。中でも， $\mathrm{L}[+]$ $\mathrm{C}[+]$ 群 $>\mathrm{L}[-] \mathrm{C}[-]$ 群であったことは，新奇なラ ベルが文脈とともに与えられるなら，子どもはむしろ 既知物を多く選択することを示している。L $[+] \mathrm{C}[+]$ 群では, 相互排他性から導かれるラベルの解釈と文脈 から導かれる解釈とが食い違う。したがって，子ども の事物選択がラベルの解釈を反映したものであるなら， この結果は，そのような葛藤事態において文脈から導 かれる解釈が優先されたことを示唆するものと言えよ う。しかし，この結果については，適切な文脈の中で ラベルが提示されるなら子どもは簡単に相互排他性制 約を乗り越えうるとの結論のほかに，2つの解釈可能 性が残されている。
その第 1 は年少児の処理容量が限られていることと 関連している。ここで $\mathrm{L}[+] \mathrm{C}[+]$ 群の子どもに対す る文脈とラベルの提示は，文脈，ラベルという順序で なされた。したがって，先に提示された文脈だけで子 どもの処理容量は満たされてしまい，そのあとで提示 されたラベルには注意が向けられなかったということ が考えられる。そこでこの点を明らかにするため, 別 に年少児 10 名 (平均 $3: 10$ ) を対象に，ラベルを先，文脈 をあとに提示する逆順条件のもとで，どのような事物 選択がなされるか, 検討した。 $\mathrm{L}[+] \mathrm{C}[+]$ 群の事物選 択がこのような処理容量の問題に起因するなら，逆順 群における既知物の選択は, $\mathrm{L}[+] \mathrm{C}[+]$ 群より少なく なるはずである。しかし，逆順群の F 得点は4.0 (1.3) で， $\mathrm{L}[+] \mathrm{C}[+]$ 群との間に差はなかった $(\mathrm{t}=1.10, \mathrm{df}=$ 24)。したがって， $\mathrm{L}[+] \mathrm{C}[+]$ 群で既知物がより多く 選択されたのは，先に提示された文脈だけで年少児の 処理容量を超えてしまい，ラベルに注意が向けられな かったためとは言えない。こうして第 1 の解釈可能性 は却下された。

第 2 の可能性は，例えば「メリーちゃんは，お腹が すいています。メリーちゃんにへクを渡してあげて」 と言われてりんごを選んだ子どもは，りんごをへクだ と考えたのではなく，“お腹がすいている”という状況 に適応的に対処しただけなのかもしれないということ である。すなわち，年少児の事物選択が，本当にラ心゙ ルをそのように解釈した結果なのかは疑わしい。特に， 前にも述べたように，子どもの語意獲得は非言語的な 反応バイアスに反した形でなされる。それゆえ，子ど もが言語を獲得していくときに従っている制約も，場 面にどう対処するかを決めるときに従っているのとは 別の，言語に固有のものとして提出された。したがつ て，事物選択という行動面のデータだけに基づいて， その存否を論ずることはできない。子どもが実際にラ ベルをどう解釈するかが，取り上げられるべきだろう (この点は Markman ら (1988) に対する第 2 の批判点とも対応 している)。そこで実験 2 では, 実験 1 の $\mathrm{L}[+] \mathrm{C}[-]$ 群, $\mathrm{L}[+] \mathrm{C}[+]$ 群の子どもが, 実際にはラベルをどの ように解釈していたのかを探り，文脈の有無がラベル の解釈に及ほす影響について検討する。

\section{実 験 2}

実験 1 では，ラベルの指すものが既知物であること を示唆するような文脈中で新奇なラベルが与えられる なら，年少児はそれに対し，むしろ既知物を多く選択 することが見いだされた。しかし，この事物選択がラ 
ベルを実際そのように解釈した結果であるかは疑わし い。また相互排他性を言語に固有の制約として提出す るなら，事物選択という行動面のデータだけに基づい て，その存否を論ずることはできないだろう。実験 2 では, 子どもの選択した事物としなかった事物の両方 について，それがラベルの指すものだと思うかを子ど もに直接尋ね, ラベルとともに提示される文脈が, 年 少児において, 既知物へのラベルの受け入れを促す(= 相互排他性に反したラベルの解釈を行わせる）効果を持つか, 検討する。

\section{方 法}

被験者 実験 1 の $\mathrm{L}[+] \mathrm{C}[$ - $]$ 群 (=文脈なし条件) と $\mathrm{L}[+] \mathrm{C}[+]$ 群 (=文脈あり条件) の被験児, 各16名。

材料 実験 1 (TABLE 1) に同じ。

手続 実験 1 の事物選択が 5 セットすべてについて 終了した後, 再び事物セットを示して, 先刻の事物選 択課題でどちらを選んだか確認する。このとき，L $[+]$ $\mathrm{C}[$ 一] 群には「さっき先生が『メリーちゃんにへクを 渡してあげて』と言ったら○○ちゃんはどちらを渡し てくれた?」, L $[+] \mathrm{C}[+]$ 群には「さっき先生が『メ リーちゃんは抢腹がすいています。メリーちゃんにへ クを渡してあげて』と言ったら○○ちゃんはどちらを 渡してくれた？」と尋ね，事物選択課題と同じ状況を 再現するよう配慮した。そうしておいて，まず被験児 が選んだ事物を指し「これはへクだと思った？」と問 う。これに対して反応がなければ，再度この質問を繰 り返す。それでも無反応なら，その事物に対するラべ ルの受け入れ拒否と見なした。さらにその後で, 子ど もが選択しなかった方の事物についても同じことを 行った。すなわち，事物選択課題で被験児が選んだ事 物, 選ばなかった事物の両方について，ラベルの受け 入れをチェックした。

得点化 各セットで一方の事物にのみ YES 反応を したとき，その事物に対するラベルの受容 (ラベルはそ の事物を指すと解釈した)と見なす。両方に YES 反応をし たり, NO反応をした場合は, ラベルの解釈が行われな かったとして, そのセットは得点化の対象にしなかっ た。得点は, 各セットでラベルが既知物を指すと解釈 された場合に 1 点とし，被験児ごとに 5 セットの合計 を求め, 既知物へのラベル受容得点（ $\mathrm{L}$ 得点）とした。

デザイン 文脈の有無で 2 条件

\section{結果と考察}

$\mathrm{L}$ 得点の平均 (SD) は, $\mathrm{L}[+] \mathrm{C}[-]$ 群が.4(.6), L $[+] \mathrm{C}[+]$ 群が.8(1.2)で両群の間に差はなく（t=1.15, $\mathrm{df}=30)$, 少なくとも年少児において文脈は, 既知物への
ラベル受容を促す効果を持たないことが示された**。 したがって，実験 1 の $\mathrm{L}[+] \mathrm{C}[+]$ 群が既知物を多く 選択したのは，必ずしも文脈を手掛かりにラベルは既 知物を指すと解釈した結果とは言えない。

では，ラベルはどのように解釈されていたのだろう か。群ごとに, ラベルは“未知物を指す”との解釈を “既知物を指す”との解釈より多く行った者の数をか ぞえると, L $[+] \mathrm{C}[-]$ 群, $\mathrm{L}[+] \mathrm{C}[+]$ 群ともに 14 名で, 符号検定において有意であった $(\mathrm{p}<.05)$ 。このこ とは，年少児が文脈の有無にかかわらず，与えられた ラベルは末知物を指すと解釈しやすいことを示唆して いる。すなわち, 年少児は, ラベルの指すものについ て他に手掛かりがなければ, 相互排他性に従って, ラ ベルは未知物を指すと解釈する。そして, ラベルが文 脈の中で提示され, 文脈から導かれるラベルの解釈(既 知物を指す) と相互排他性から導かれる解釈 (未知物を指 す)が食い違うときにも，彼らは，相互排他性を優先さ せ, ラベルは未知物を指すと解釈するのである。この 結果は, 年少児において, 相互排他性が, ラベルの他 の解釈可能性を排し効率よく語意に達せしめる制約と して存在していることを示すものであろう。

以上, 実験 2 では, より厳密な事態において相互排 他性制約の存在を確かめることができた。そして，こ のような制約の存在は，子どもが効率的に語を学習し ていくことばかりでなく，りんごは“りんご”である と同時に“果物”でもあるというように 1 つの事物が 類包摄関係にある複数の名称で指示されうることが, 子どもには理解し難い (Inhelder \& Piaget, 1964 ; Mac namara, 1982)'ことも説明する。

しかし，子どもはいずれ上位語を獲得し，りんごは “りんご”であると同時に“果物”でもあることを受 け入れるようになっていく。したがってその過程で, 1 つの事物に 1 つの名称しか認めないという制約は乗 り越えられなければならない。それは,いつ頃, どの ような形で達せられるのであろうか。年齢が進むにつ れ，相互排他性という概念そのものが捨て去られ，新 奇なラベルを解釈する際にもそのような方略が使われ なくなるということなのだろうか。それとも， ラベル

** 念のため“未知物にラベルを受け入れる反応”“無反応”につ いても得点化し分析した。得点の平均(SD) はそれぞれ， L $[+]$ $\mathrm{C}[-]$ 群が $3.1(1.7), 1.5(1.5), \mathrm{L}[+] \mathrm{C}[+]$ 群が2.3(1.8), 1.9 (1.8)で, どちらの得点についても群間に有意な差は見出されな かった (末知物へのラベル受容 $\cdots \mathrm{t}=1.27$, 無反応 $\cdots \mathrm{t}=.65 ; \mathrm{df}=$ $30)$ 。 
の指すものが文脈から明らかなときには，相互排他性 よりそのような文脈を重視してラベルを解釈するとい うように，相互排他性という方略がより柔軟に使い分 けられるようになるということなのだろうか。以下で は,これまでと同様の事態において, 事物選択を行っ たり (実験 3) ラベルを解釈したり (実験 4) するときに相 互排他性や文脈を利用する仕方は, 年齢が進むにつれ どのように変化していくのかについて，3〜 5 歳児を 対象に検討する。

\section{実 験 3}

\section{方 法}

被験者 保育園の年少児，年中児，年長児各 64 名， (年少児は実験 1 と同じ) が16名ずつ 4 条件にわりあてら れた(男女比 $1: 1$ )。年少児は, $\mathrm{L}[-] \mathrm{C}[-]$ 群が平均 3 ： 10 , レンジ $3: 4 \sim 4: 4, \mathrm{~L}[-] \mathrm{C}[+]$ 群が平均 3 : 10 , レンジ $3: 4 \sim 4: 5, \mathrm{~L}[+] \mathrm{C}[-]$ 群が平均 3 : 10 , レンジ $3: 4 \sim 4: 5, \mathrm{~L}[+] \mathrm{C}[+]$ 群が平均 3 : 11 , レンジ $3: 5 \sim 4: 3$, 年中児は, $\mathrm{L}[-] \mathrm{C}[-]$ 群 が平均 $4: 9$, レンジ $4: 6 \sim 5: 4, \mathrm{~L}[-] \mathrm{C}[+]$ 群 が平均 $4: 10$, レンジ $4: 6 \sim 5: 3, \mathrm{~L}[+] \mathrm{C}[-]$ 群 が平均 $4: 10$, レンジ $4: 6 \sim 5: 3, \mathrm{~L}[+] \mathrm{C}[+]$ 群 が平均 $4: 10$, レンジ $4 ： 6 \sim 5 ： 4$, 年長児は, $\mathrm{L}[-] \mathrm{C}[-]$ 群が平均 $5: 11$, レンジ $5: 8 \sim 6: 4$, $\mathrm{L}[-] \mathrm{C}[+]$ 群が平均 $5: 10$, レンジ $5: 6 \sim 6: 2$, $\mathrm{L}[+] \mathrm{C}[-]$ 群が平均 $5: 10$, レンジ $5: 7 \sim 6: 3$, $\mathrm{L}[+] \mathrm{C}[+]$ 群が平均 $5: 10$, レンジ $5: 6 \sim 6: 4$ であった。

材料 手続 得点化 実験 1 に準じる。

デザイン 年齢 $(3) \times$ ラベルの有無 $(2) \times$ 文脈の有無 $(2)$

\section{結果と考察}

$\mathrm{F}$ 得点の平均 (SD) は, TABLE 2 に示した。

TABle 2 Mean (SD)s of F-Scores (Scores for the Selection of Familiar Object) in Experiment 3.

\begin{tabular}{lcccc}
\hline $\begin{array}{l}\text { condition } \\
\text { age }\end{array}$ & $\mathrm{L}[-] \mathrm{C}[-]$ & $\mathrm{L}[-] \mathrm{C}[+]$ & $\mathrm{L}[+] \mathrm{C}[-]$ & $\mathrm{L}[+] \mathrm{C}[+]$ \\
\hline 年少児(3) & $2.6(0.8)$ & $4.7(0.7)$ & $1.1(1.0)$ & $3.4(1.3)$ \\
\hline 年中児(4) & $2.7(1.0)$ & $4.9(0.3)$ & $1.6(1.6)$ & $3.6(1.2)$ \\
\hline 年長児(5) & $3.1(1.4)$ & $4.9(0.3)$ & $1.7(1.6)$ & $4.9(0.3)$ \\
\hline
\end{tabular}

この得点について 3 要因の分散分析を行ったところ, 年齢 $(F(2,180)=7.12)$, ラベル $(F(1,180)=51.64)$, 文脈 $(F$
$(1,180)=210.46)$ の主効果がすべて $0.1 \%$ 水準で有意で あった。Scheffe 法により対間比較を行うと, 年歯につ いては年少児と年長児の間に有意な差があり（p<.05）, 年長児は全体に，年少児より既知物を多く選択してい た。ラベルの主効果は, ラベルの提示により既知物が 選択されにくくなること, 文脈の主効果は, 文脈が与 えられることによって既知物がより多く選択されるよ うになることを示すものであった。またここで，交互 作用が有意にならなかったということは，このような 事物選択のパターンが年齢を通じて変わらないことを 示唆している。したがって, 事物選択に際して相互排 他性や文脈を利用する仕方に， $3 \sim 5$ 歳児で年齢によ る違いはないと言えよう。

ここから以下のような示唆を得ることができる。

第 1 に，子どもがやがて相互排他性制約を乗り越え， 同じ 1 つの事物が “りんご”であると同時に“果物” でもあることを理解できるようになっていくのは, 単 純に, 年齢が進むつれ, 相互排他性という概念が捨て 去られ, 課題解決の方略としても使われなくなるため とは言えない。

第 2 に，文脈が既知物を選択するよう方向づける効 果は, どの年齢においても変わらない。すなわち，ラ ベルと文脈の両方が与えられる条件 $(\mathrm{L}[+] \mathrm{C}[+]$ 群) において, 文脈を重視しそれに適合した既知物を選ぶ ことは，年少児でも年長児と同様に行っているのであ る。したがって, 実験 2 で $\mathrm{L}[+] \mathrm{C}[+]$ 群の年少児 が，文脈より相互排他性にそったラベルの解釈を行っ たのは，彼らが文脈的に与えられた情報を十分に利用 できないためではない。年少児は，年長児と同じょう に文脈を理解し利用することができるにもかかわらず， ラベルを解秎するにあたつては，敢えてそれを利用し ないのだと言える。このことは再び，相互排他性制約 が，ラベルの解釈に限って適用される, 言語という領 域に固有のものであることを示唆している。したがっ て相互排他性が, いつ頃, どのような形で乗り越えら れていくのかという問題も, ラベルの解积という認知 的な操作の次元において捉えられねばならないだろう。 実験 4 では, ラベルの解釈に㧍ける, 相互排他性や文 脈の利用の発達的変化について $3 \sim 5$ 歳児を対象に検 討する。

\section{実 験 4}

\section{方 法}

被験者 実験 3 の $\mathrm{L}[+] \mathrm{C}[-]$ 群と $\mathrm{L}[+] \mathrm{C}[+]$ 群 の被験児。すなわち，保育園の年少児，年中児，年長 
児各32名が，16名ずつ文脈の有無で 2 つの条件にわり あてられた。

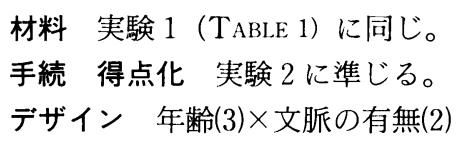

\section{結果と考察}

L 得点の各条件での平均は, FIG. 1 に示した。

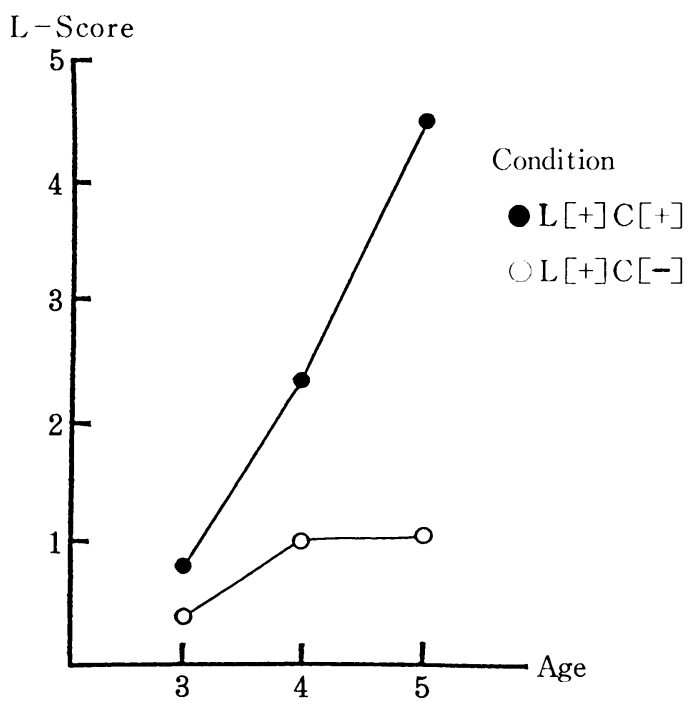

Fig. 1 L-Scores (Label Acceptance Scores for Familiar Object) in Experiment 4.

年歯 $\times$ 文脈で 2 要因の分散分析を行ったところ，年 歯合 $(F(2,90)=27.07)$ と文脈 $(F(1,90)=48.31)$ の主効果, そ の交互作用 $(\mathrm{F}(2.90)=14.40)$ が $0.1 \%$ 水準で有意であつ た。Tukey法による対間比較から，L得点は年長児・ $\mathrm{L}[+] \mathrm{C}[+]$ 群が，年中児・L $[+] \mathrm{C}[+]$ 群より有意に 高く，年中児・L $[+] \mathrm{C}[+]$ 群は残りの 4 群より有意に 高いことが示された ( $\mathrm{p}<.05)$ 。すなわち，ラベルを解釈 するための手掛かりが特に与えられないとき ( $\mathrm{L}[+] \mathrm{C}$ [一]群において), “ラベルが既知物を指す”との解釈は 行われにくく，この点で年歯による違いは認められな い。これに対し，ラベルの指すものが既知物であるこ とを示唆するような文脈中で新奇なラベルが提示され る条件 $(\mathrm{L}[+] \mathrm{C}[+]$ 群 $)$ では, “ラベルが既知物を指す” との解釈は, 年齢が進むにつれ増えることが示唆され だ**。

また，この結果を年齢ごとに見るなら，まず年少児 においては, 文脈の有無はラベルの解釈の仕方にほと
んど影響を与えていない。これに対し，年中㚾，年長 児では, 文脈が与えられることによって，ラベルは既 知物を指すとの解釈が増える。そして, 文脈のこのよ うな影響力は，年中児より年長児の方が大きなものと なっている。以上のようなことが, L得点についての 分析から見いだされた。

さらに各条件でラベルがどのように解釈されていた のかを明らかにするために，5セット中で “ラベルが 既知物を指す”との解釈を “未知物を指す”との解釈 より多く行った者の数を数え, 群ごとに符号検定を 行った (TABLE 3)。その結果, まず文脈の与えられな い条件 $(\mathrm{L}[+] \mathrm{C}[-]$ 群) では, どの年歯の子どもも“ラ ベルは未知物を指す”と解釈しやすいことが見いださ れた。一方, 文脈の与えられる条件 $(\mathrm{L}[+] \mathrm{C}[+]$ 群 $)$ で, 年少児はラベルが“未知物を指す”と解釈しがち であるが，年中児になると，“末知物を指す”とするか “既知物を指す”とするかで，どちらの解釈がより多 くなされるといった偏りはなくなり，年長児ではむし ろ, “既知物を指す”との解釈が優勢になることが示さ れた。

TABLE 3 The Number of Children who interpreted novel labels in the following way. $(\mathrm{F}=$ interpretation that the given label represents Familiar Object. : $\mathrm{U}=$ interpretation that the label represents Unfamiliar Object.)

\begin{tabular}{lcccc}
\hline condition & age & $\mathrm{F}>\mathrm{U}$ & $\mathrm{F}<\mathrm{U}$ & $\mathrm{F}=\mathrm{U}$ \\
\hline \multirow{2}{*}{$\mathrm{L}[+] \mathrm{C}[-]$} & 年少児 $(3)$ & 2 & $14^{*}$ & 0 \\
\cline { 2 - 5 } & 年中児 $(4)$ & 3 & $11^{*}$ & 2 \\
\cline { 2 - 5 } & 年長児 $(5)$ & 4 & $10^{+}$ & 2 \\
\hline \multirow{2}{*}{$\mathrm{L}[+] \mathrm{C}[+]$} & 年少児 $(3)$ & 2 & $14^{*}$ & 0 \\
\cline { 2 - 5 } & 年中児 $(4)$ & 8 & 7 & 1 \\
\cline { 2 - 5 } & 年長児 $(5)$ & $16^{*}$ & 0 & 0 \\
\hline
\end{tabular}

$$
(* \cdots p<.05 \quad+\cdots p<.10)
$$

***一方, 未知物へのラベル受容得点の平均 (SD) は, 年少児・ $\mathrm{L}[+] \mathrm{C}[-]$ 群が $3.1(1.7)$, 年少児・ $\mathrm{L}[+] \mathrm{C}[+]$ 群が $2.3(1$. $8)$ ，年中览・ $\mathrm{L}[+] \mathrm{C}[-]$ 群が $3.2(1.7)$ ，年中児 $\cdot \mathrm{L}[+] \mathrm{C}[+]$ 群が $1.8(1.3)$ ，年長児・ $\mathrm{L}[+] \mathrm{C}[-]$ 群が $2.4(1.6)$, 年長睍・ $\mathrm{L}$ $[+] \mathrm{C}[+]$ 群が.1 (.3) で, 分散分析の結果, 年齢 $(\mathrm{F}(2,90)=8$. 80）と文脈 $(\mathrm{F}(1,90)=26.58)$ の主効果が有意で（p<.001），交 互作用に有意な傾向があった $(\mathrm{F}(2,90)=2.47, \mathrm{p}<.1)$ 。文脈の有 無で分けて分析すると, 文脈なし条件では年粭差がない（F $(2$, $45 ＝ .96 ）$ が，文脈あり条件では [年少，年中児]> [年長児] で，末知物にラベルを受容する反応は，既知物にラベルを受哀 する反応とほぼ相補的な関係にあることが示唆された。なお， 無反応得点については，いっさい有意差は見られなかった。 
以上より，第 1 に，手掛かりがないとき相互排他性 を方略的に用いてラベルを解釈することに年齢差はな いこと，第 2 に，年少児は文脈の有無にかかわらず相 互排他性に従って “ラベルは未知物を指す”と解釈し がちであるが，年長児になると，ラベルの指すものが 既知物であることを示すような文脈中でラベルが提示 されるなら，それに基づき，“ラベルは既知物を指す” と積極的に解釈するようになることが示唆された。

では，年長児になると，文脈を支えに“ラベルは既 知物を指す”と積極的に解釈するようになるのは, 子 どもにどのような変化が起こったということなのだろ うか。

これを単純に, 年長児は年少児より, 文脈をよく理 解でき利用できるためと言うことはできない。実験 3 の事物選択からは，年少児も，年長児と同じように文 脈を利用することが示されている。むしろ年少児は, 文脈を利用することができるにもかかわらず，ラベル を解釈するにあたっては敢えてそれを利用しようとし ないのだと言える。

また，年齢が進むにつれて，相互排他性という概念 そのものが捨て去られ, 方略として用いられなくなる わけでもないらしい。実験 3 および実験 4 の結果は, 事物選択をしたりラベルを解釈したりするとき，他に 手掛かりがないなら，どの年踰の子どもでも同じよう に，相互排他性を方略的に用いることを示している。 このように，年少児と年長児とでは利用することの できる方略のレパートリーが異なっているわけではな い。違うのは, 数ある利用可能な方略の中から, ラべ ルを解釈するにあたって（そしてそのような領域に限って）， どれを選び適用していくかなのである。例えば，ラべ ルの指すものが既知物であることを示唆するような文 脈の中で新奇なラベルが提示されたとき，年少児がラ ベルは末知物を指すと解釈するのは, 彼らが, ラベル を解釈するにあたっては, ラベルと事物を 1 対 1 に対 応づけることに重きをおき，それに対応した解釈方略 をとっているからであろう。また，年長児が同じ事態 において, ラベルは既知物を指すと解釈するのは, 彼 らが，ラベルと事物との対応関係より, そのラベルが どのような文脈で使われたかを重視して, ラベルの解 釈を行っているということにほかならない。そしてこ のように，年齢を追うにつれ，ラベルを解釈するにあ たって違う方略を採るようになっていく，その結果と して，1つの事物に 1 つの名前しか認めないという相 互排他性制約も，乗り越えられていくのであろうと考 えられる。

\section{全体的討論}

子どもの語彙獲得は多くが指示定義を通じてなされ る。しかし指示定義は, 語が対象のどのような側面を 指すのか明らかにしない点で, 曖昧である。子どもは そこからどのようにして語意を明らかにするのか。

相互作用論の立場（例えば Nelson, 1988）からは，これ が，他者とやりとりする中で，1つ1つの語意仮説を 文脈に照らして検証していくような, 複雑な推論のプ ロセスであると見なされる。しかし, 子どもの語彙獲 得が非常な速さで進むことを考えると, 彼らが語意を 明らかにするため, いちいち複雑な推論を行っている とは考えにくい。他者との相互作用をまつまでもなく， 子どもが効率よく語意に達することを可能にしている ような制約が働いており，子どもが語意についてどの ような仮説を立てるかを決定しているに違いない。

この制約理論の立場はさらに, 制約を, 非言語的な 反応バイアスと同一視するか, 言語に固有なものと見 なすかによって二分される。しかし子どもは, 分類課 題などにおいては事物のカテゴリ一関係より主題関係 を選好するにもかかわらず, 語は事物のカテゴリ一名 として学習する。このように, 語彙獲得がむしろ非言 語的な反応バイアスに反した形でなされることを考え るなら, 制約を言語に固有なものと見なす, 後者の立 場がより妥当なものと考えられる。

‘子どもは一事物一名称の仮定を持つ’ とする相互排 他性制約も，このような制約の 1 つとして提出されて きた (Markman, 1987, 1989)。したがって，その存在を裏 づけるには，第 1 に，相互排他性にもとづく語の解釈 が，文脈などから導かれる他の解釈より優先されるこ と，第 2 に，子どもは与えられた語の指示対象を明ら かにするとき実際にそのような方略を用いていること が示されねばならない。したがって, 未知物と既知物 のうちから 1 つを選ぶ課題で，新奇なラベルが提示さ れると, 年少児は末知物をより多く選択するように なった (Markman \& Wachtel, 1988) というだけでは, こ のような制約の存在を示すものとして不十分であろう。 そこで本研究は, 先行研究のこのような問題点を克 服し, より厳密な事態において相互排他性制約の存在 を検討することを，第 1 の目的とした。具体的には， ラベルの指すものが既知物であることを示唆するよう な文脈中で新奇なラベルが提示される条件を設定し, それが，年少児の事物選択 (実験 1) やラベルの解釈 (実 験 2)にどう影響するかを調べた。

その結果, 実験 1 では, このような文脈の中でラべ 
ルが提示されるなら，年少児はそれに対して既知物を より多く選ぶようになることが示された。しかし実験 2 でラベルの解釈を調べると, (1)文脈は既知物へのラ ベル受け入れを促進するような効果を持たず，むしろ， (2)ラベルは文脈の有無にかかわらず末知物の名前と解 釈されやすいことが見いだされた。

この第 1 の点 (1)） から, 実験 1 で文脈の提示に対 して既知物が多く選択されたのは，必ずしも文脈を手 掛かりにラベルが既知物を指すと解釈されたためでは ないことが示唆される。むしろ，このような実験 1 と 実験 2 の結果のずれは, ラベルの解釈が, 行動の上で 課題にどう対処するかを決める際に子どもが従ってい るのとは別の, 言語に固有の規則に従ってなされてい ることを示唆するものであろう。

また第 2 の点（2）は, 特にラベルが文脈の中で提 示される条件では, 相互排他性から導かれるラベルの 解釈 (未知物を指す) と文脈から導かれる解釈 (既知物を指 す)とは葛藤するにもかかわらず, 前者が優先されたこ とを示している。すなわち，ラベルを解釈するとき年 少児は, 箃密に相互排他性という規則に従っていると 言うことができるだろう。

このように実験 2 では, 子どもがラベルの解釈とい う領域に限って厳密に適用していくような規則，すな わち, 言語に固有の制約として, 相互排他性制約が存 在することを, より厳密な事態において確かめること ができた。そして，このような制約の存在は, りんご が“りんご”であると同時に“果物”でもあるという ように，1つの事物が類包攝関係にある複数のラベル によって指示されうることを子どもが受け入れ難いこ とをも説明する。しかし，子どもはいずれ上位語を獲 得し，1つの事物の上で抽象度の異なる複数のラベル が重なり合うことを理解できるようになっていく。そ の過程で, このような制約は乗り越えられなければな らない。それは, いつ頃, どのような形で達せられる のだろうか。この点を明らかにするのが, 本研究の第 2 の目的であった。そして具体的には, 事物選択 (実験 3）やラベルの解釈 (実験 4) において, 相互排他性や文 脈を利用する仕方に，3〜5歳で何か変化は見られる のか, 見られるとすれば，それはどのような変化なの かが検討された。

その結果，まず実験 3 からは, 事物選択に際して相 互排他性や文脈を利用する仕方は, どの年齢において も変わらないことが見いだされた。すなわち，相互排 他性という方略は，年齢とともに捨て去られ使われな くなるわけでもなく, 年少児と年長児では, 文脈を利
用する力に差があるわけでもないことが示唆された。 一方, ラベルの解釈については, “手掛かりがないと き相互排他性にたよって “ラベルは未知物を指す”と しがちなのは，どの年齢でも同じであること’，“文脈 の中でラベルが提示された場合，年少児は,“ラベルは 未知物を指す”と解釈しがちであるが，年中児では， ラベルが “既知物を指す”とするか“未知物を指す” とするかでどちらの解釈が優勢ということはなくなり， 年長児にいたっては，“ラベルは既知物を指す”との解

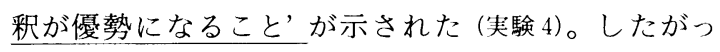
て，適切な文脈の中でラベルが与えられたとき，それ を支えにラベルは既知物のもう 1 つの名前であると積 極的に認めるようになるのは，年長児以降なのであろ う。

しかし，年長児がこのように相互排他性制約を乗り 越え，既知物に対して積極的に複数のラベルを受け入 れるようになるのは, 実験 3 や実験 4 から示唆される ように，子どもが利用することのできる方略のレパー トリーに変化が起こったということではない。おそら く, 年少児と年長児では, ラベルを解釈するにあたっ て, 数ある利用可能な方略の中からどれを選びだすか が違うだけなのである。そして，年齢にともなう変化 がこのようにラベルを解釈するのに違う方略を用いる ようになるということであるなら，その基礎にはさら に，ラベルの解釈という行為そのものを支配している， 子どもなりの “言語観” といったものの変化があるこ とが示唆されよう。すなわち, 年少児が, そのラベル がどのような文脈で使われたかより，事物との対応関 係を重視して，その指示対象を明らかにしようとする のであれば，それは，彼らがラベルを，事物が与えら れれば一意に決まるもののように見なしているためと 考えられる。しかし，事物とラベルとの結びつきは本 来, 恣意的なものである。我々が, 同じ 1 つの対象を 指示するのに“りんご”“食べ物”など複数のラベルを 使い分けるのは，対象から文脈に応じた抽象度で情報 を取り出そうとするからにほかならない。子どもが, 文脈と相互排他性の葛藤する事態において, より文脈 を重視してラベルを解釈するようになるとき，そのよ うな変化は, 彼らの“言語観”の中でことばの恣意性 が理解され始めたことを反映しているのかもしれない。 もちろん, このように考えることは，まだ今の段階で は憶測の域を出ない。子どもの中でラベルを解釈する 方略が変化するとき, その裏にはどのような“言語観” の変化があるのか, 明らかにすることは, 今後の課題 であろう。 


\section{引用文献}

Bruner, J.S., Olver, R.R. \& Greenfield, P.M. 1966 Studies in cognitive growth. London \& New York : Wiley. 岡本夏木 他（訳）認識能力の 成長 明治図書

Carey, S. 1982 Semantic development : the state of the art. In E. Wanner \& L.R. Gleitman (Eds.), Language acquisition : the state of the art. London \& New York : Wiley.

Clark, E.V. 1973 Non-linguistic strategies and the acquisition of word meanings. Cognition, $2,161-182$.

Clark, E.V. 1977 Strategies and mapping problem in first language acquisition. In J.Macnamara (Ed.), Language learning and thought. New York : Academic Press.

Clark, H.H. \& Clark, E.V. 1977 Psychology and language. Harcourt Brace Jovanovitch, Inc. 藤永保 他（訳） 心理言語学 新曜社.

Gelman, R. \& Baillargeon, R. 1983 A review of some Piagetian concepts. In P.H. Mussen (Ed.), Handbook of child psychology, vol. 3. New York : Wiley.

Inhelder, B. \& Piaget, J. 1964 The early growth of logic in the child. London : Routledge \& Kagan Paul.

Macnamara, J. 1982 Names for things : a study of human learning. Cambridge : MITPress.

Markman, E.M. 1987 How children constrain the possible meanings of words. In U.Neisser (Ed.), Concepts and conceptual development. Cambridge : Cambridge University Press.

Markman, E.M. 1989 Categorization and naming in children : problems of induction. Cambridge : MITPress.

Markman, E.M. \& Hutchinson, J.E. 1984 Chil- dren's sensitivity to constraints on word meaning : taxonomic versus thematic relations. Cognitive Psychology, 16, 1-27.

Markman, E.M. \& Wachtel, G.F. 1988 Children's use of mutual exclusivity to constrain the meanings of words. Cognitive Psychology, 20, 121-157.

Mervis, C.B. 1980 Category structure and the development of categorization. In R.J. Spiro, B.C. Bruce \& W.F. Brewer (Eds.), Theoretical issues in reading comprehension. Hillsdale : LEA

Nelson, K. 1988 Constraints on word learning ? Cognitive Development, 3, 221-246.

Quine, W.V.O. 1960 Word and object. Cambridge : MITPress. 大出泉・宮館恵（訳）ことばと 対象 勁草書房

Smiley, S. S. \& Brown. A.L. 1979 Conceptual preference for thematic or taxonomic relations : a nonmonotonic age trend from preschool to old age. Journal of Experimental Child Psychology, 28, 249-257.

鈴木孝夫 1973 ことばと文化 岩波新書

梅本克夫・森川弥寿雄・伊吹昌夫 1955 清音 2 字音 節の無連想価及び有意味度 心理学研究, 26, 148 -155 .

$$
\text { 付 記 }
$$

実験の実施にあたっては，日野市役所児童課の三上 課長補佐, 市内保育園の諸先生方, 園児の皆さんにご 協力いただきました。また論文の作成過程では，東京 大学の大村彰道先生, 抢茶の水女子大学の内田伸子先 生のご助言をいただき，統計処理に関しては，東京大 学の平直樹氏，斎木潤氏に相談にのっていただきまし た。以上の方々に心より感謝申し上げます。

(1990 年 2 月 13 日受稿) 